\title{
Cultural Resource Investigations for the Remote Handled Low Level Waste Facility at the Idaho National Laboratory
}

Brenda R. Pace Hollie Gilbert Julie Braun Williams

Clayton Marler Dino Lowrey Cameron Brizzee

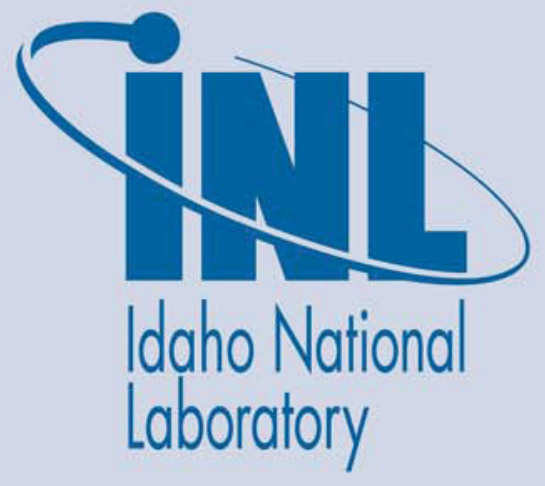

June 2010

The INL is a U.S. Department of Energy National Laboratory operated by Battelle Energy Alliance 


\section{DISCLAIMER}

This information was prepared as an account of work sponsored by an agency of the U.S. Government. Neither the U.S. Government nor any

agency thereof, nor any of their employees, makes any warranty, expressed or implied, or assumes any legal liability or responsibility for the accuracy, completeness, or usefulness, of any information, apparatus, product, or process disclosed, or represents that its use would not infringe privately owned rights. References herein to any specific commercial product, process, or service by trade name, trade mark, manufacturer, or otherwise, does not necessarily constitute or imply its endorsement, recommendation, or favoring by the U.S. Government or any agency thereof. The views and opinions of authors expressed herein do not necessarily state or reflect those of the U.S. Government or any agency thereof. 


\title{
Cultural Resource Investigations for the Remote Handled Low Level Waste Facility at the Idaho National Laboratory
}

\author{
Brenda R. Pace \\ Hollie Gilbert \\ Julie Braun Williams \\ Clayton Marler \\ Dino Lowrey \\ Cameron Brizzee
}

June 2010

\begin{abstract}
Idaho National Laboratory Cultural Resource Management Idaho Falls, Idaho 83415
\end{abstract}

http://www.inl.gov

Prepared for the

U.S. Department of Energy

Office of Nuclear Energy

Under DOE Idaho Operations Office

Contract DE-AC07-05ID14517 
INTENTIONALLY BLANK 


\begin{abstract}
The U. S. Department of Energy, Idaho Operations Office is considering options for construction of a facility for disposal of Idaho National Laboratory (INL) generated remote-handled low-level waste. Initial screening has resulted in the identification of two recommended alternative locations for this new facility: one near the Advanced Test Reactor (ATR) Complex and one near the Idaho Comprehensive Environmental Response, Compensation, and Liability Act Disposal Facility (ICDF). In April and May of 2010, the INL Cultural Resource Management Office conducted archival searches, intensive archaeological field surveys, and initial coordination with the Shoshone-Bannock Tribes to identify cultural resources that may be adversely affected by new construction within either one of these candidate locations. This investigation showed that construction within the location near the ATR Complex may impact four archaeological resources, including two that are potentially eligible for nomination to the National Register of Historic Places. Construction in the candidate location near the ICDF may impact two archaeological resources, including one that exhibits potential for National Register listing. Generalized tribal concerns regarding protection of natural resources were also documented in both locations. This report outlines recommendations for protective measures to help ensure that the impacts of construction on the identified resources are not adverse.
\end{abstract}


INTENTIONALLY BLANK 


\section{Acknowledgements}

These cultural resource investigations were accomplished by a diverse team from the Idaho National Laboratory's Cultural Resource Management Office. Julie Braun Williams is the cultural resources team lead. Archaeological surveys were coordinated by Hollie Gilbert with assistance from Julie Braun Williams, Dino Lowrey, and Clayton Marler. Clayton Marler also escorted tribal representative Caroline Smith from the Shoshone-Bannock Tribe's Heritage Tribal Office to the project area and Caroline kindly provided input on tribal concerns. Brenda Pace prepared the report with editorial and formatting assistance from Cheryl Swank. The final document is also enhanced by artifact sketches created by Dino Lowrey and maps created by Cameron Brizzee. 
INTENTIONALLY BLANK 


\section{CONTENTS}

Abstract

Acknowledgements

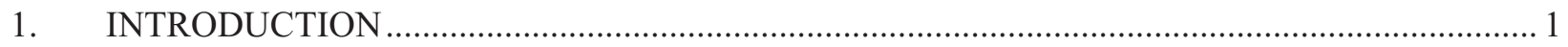

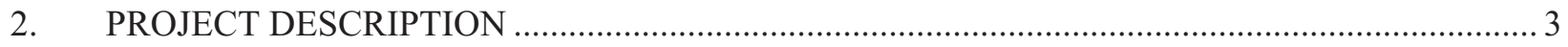

2.1 Area of Potential Effects ........................................................................................... 4

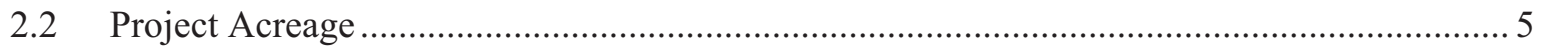

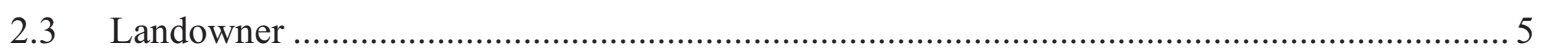

3. STATEMENT OF OBJECTIVES FOR INVESTIGATIONs ..................................................... 6

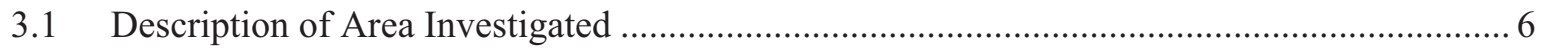

3.2 Amount and Types of Information Collected .............................................................. 6

4. LOCATION AND GENERAL ENVIRONMENTAL SETTING …............................................ 7

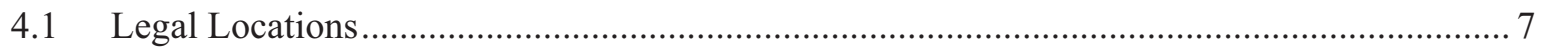

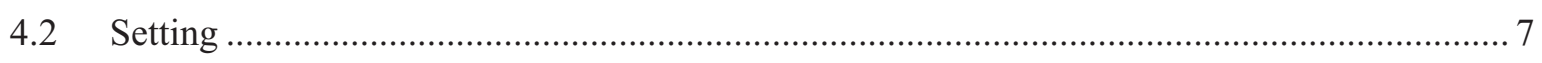

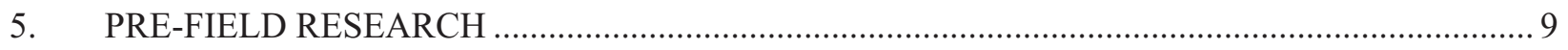

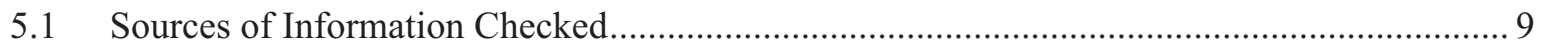

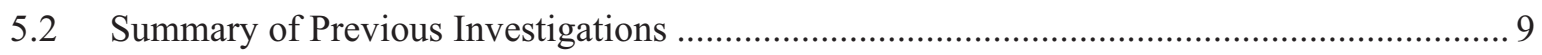

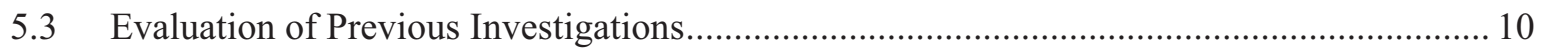

6. EXPECTED HISTORIC AND PREHISTORIC LAND USE AND SITE DENSITY ................... 11

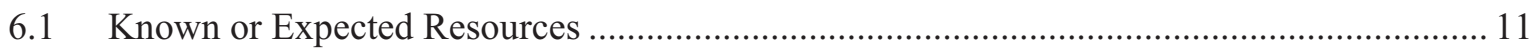

6.2 Known or Expected Themes, Time Periods, and INL Contexts ......................................... 11

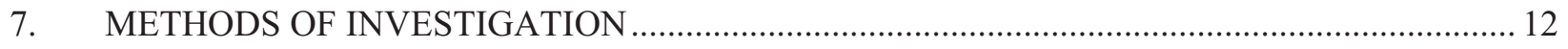

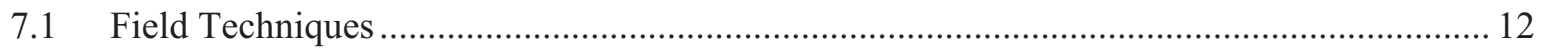

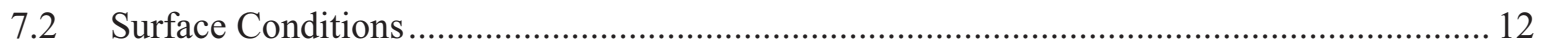

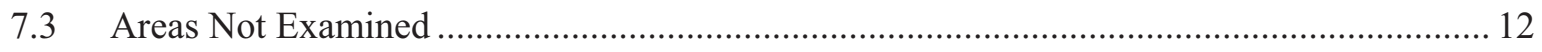

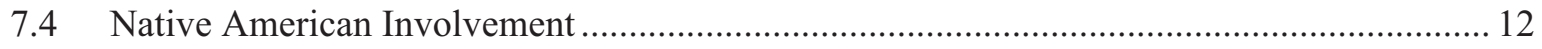

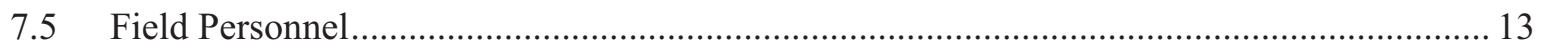

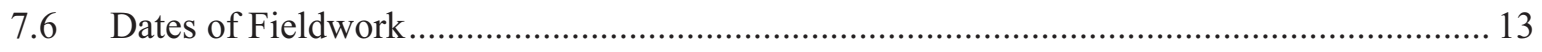

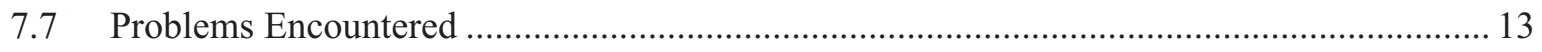

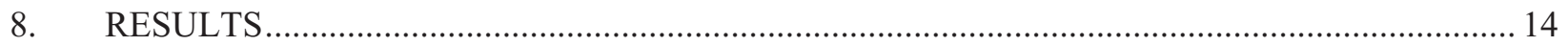

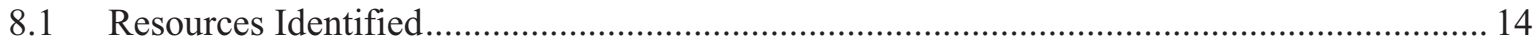

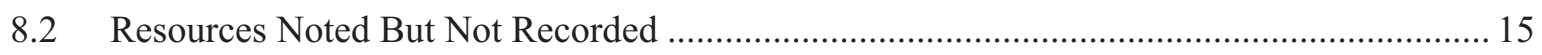

8.3 Summary of Important Characteristics of Identified Resources ........................................ 15

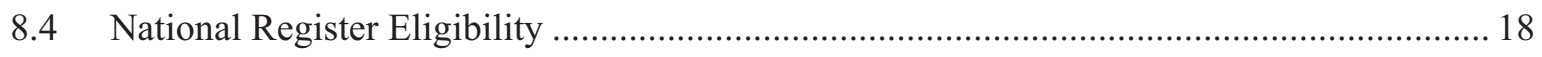




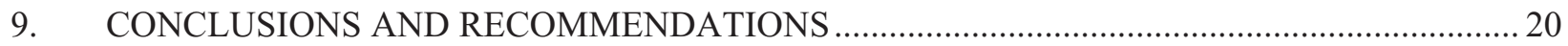

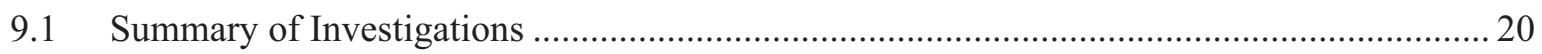

9.2 Potential Threats to Identified Resources ........................................................................ 20

9.3 Recommendations for Additional Investigations or Protective Measures ........................... 21

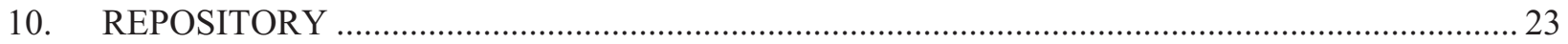

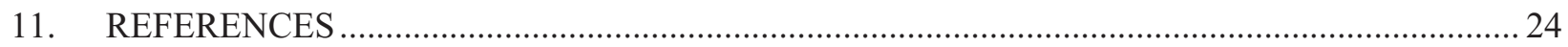

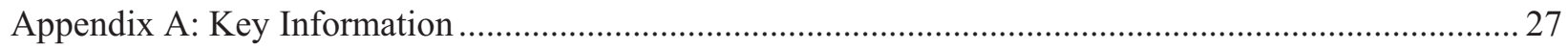

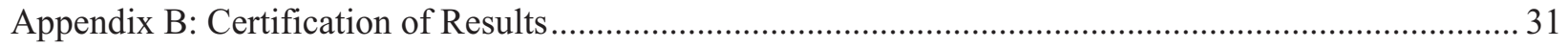

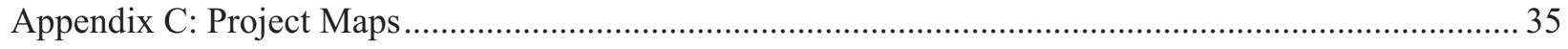

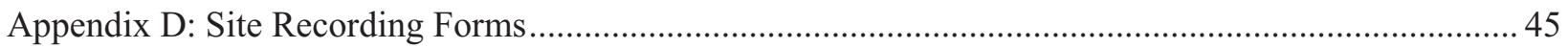

\section{FIGURES}

Figure 1. General location of the Idaho National Laboratory............................................................... 1

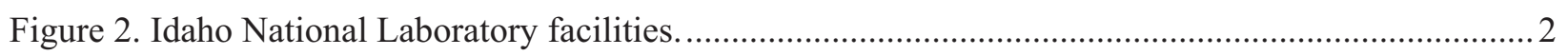

Figure 3. Conceptual layout for the proposed Remote Handled Low Level Waste Disposal Facility (based on Harvego et al. 2010b:4-1). ....................................................................... 3

Figure 4. Candidate locations for construction of the Remote Handled Low Level Waste Facility

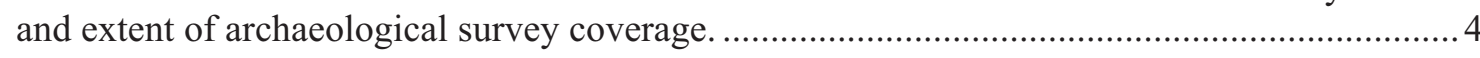

Figure 5. Isolated artifacts discovered during the RH LLW surveys: large notched point fragment from BEA-10-10-3 (A) and retouched flake from BEA-10-10-4 (B) ..................................... 15

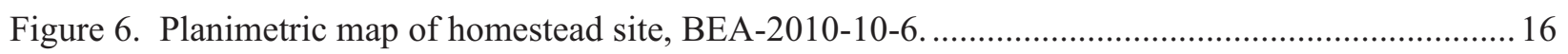

Figure 7. Sewing machine stand discovered at homestead site BEA-2010-10-6.................................. 16

Figure 8. Secondary canal (BEA-10-10-5) extending left to right through lower portion of photo

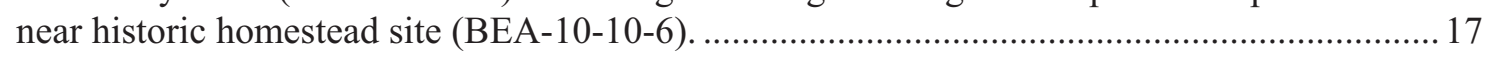

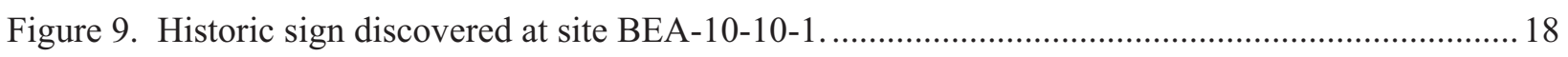

\section{TABLES}

Table 1. Legal locations for candidate locations for RH LLW facility construction................................. 7

Table 2. General themes and time periods anticipated in the project area............................................... 11

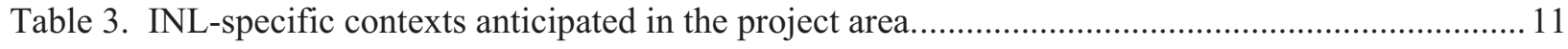

Table 4. Archaeological resources identified in the two candidate locations for RH LLW construction. 14

Table 5. National Register evaluations for archaeological resources identified in the two candidate locations for RH LLW construction. 


\title{
ACRONYMS
}

\author{
AIP Agreement in Principle \\ ATR Advanced Test Reactor \\ BEA Battelle Energy Alliance \\ BT Butte (county) \\ BP before present (years) \\ CERCLA Comprehensive Environmental Response, Compensation, and Liability Act \\ CFA Central Facilities Area \\ CRM cultural resource management \\ CWI CH2M-WG Idaho, LLC \\ DOE-ID Department of Energy-Idaho Operations Office \\ $\mathrm{ft} \quad$ feet \\ GIS geographical information systems \\ GPS global positioning system \\ ICDF Idaho CERCLA Disposal Facility \\ INL Idaho National Laboratory \\ INTEC Idaho Nuclear Technology and Engineering Center \\ m meters \\ RH LLW remote-handled low-level waste \\ RWMC Radioactive Waste Management Complex \\ NRF Naval Reactors Facility \\ NRHP National Register of Historic Places \\ SHPO State Historic Preservation Office \\ U.S. United States
}


INTENTIONALLY BLANK 


\section{Cultural Resource Investigations for the Remote Handled Low Level Waste Facility at the Idaho National Laboratory}

\section{INTRODUCTION}

The Idaho National Laboratory (INL) is an 890 square mile federal reserve covering portions of five counties on the northeastern edge of the Snake River Plain in southeastern Idaho (Figure 1). INL lands and facilities are under the jurisdiction of the U.S. Department of Energy, Idaho Operations Office (DOEID) and have been set aside since the 1940s to support science and engineering in nuclear energy and other disciplines (Stacy 2000). The Laboratory has also been designated a National Environmental Research Park, dedicated to the study of the environmental impacts of energy research (Irving 1993), and a portion of the land has been set aside as a Sagebrush Steppe Ecosystem Reserve. Cultural resources including historic and prehistoric archaeological sites, historic architectural properties, and areas of importance to the Shoshone-Bannock Tribes and others are numerous across the Laboratory and are managed in accordance with the DOE-ID's Cultural Resource Management (CRM) Plan (DOE-ID 2009).

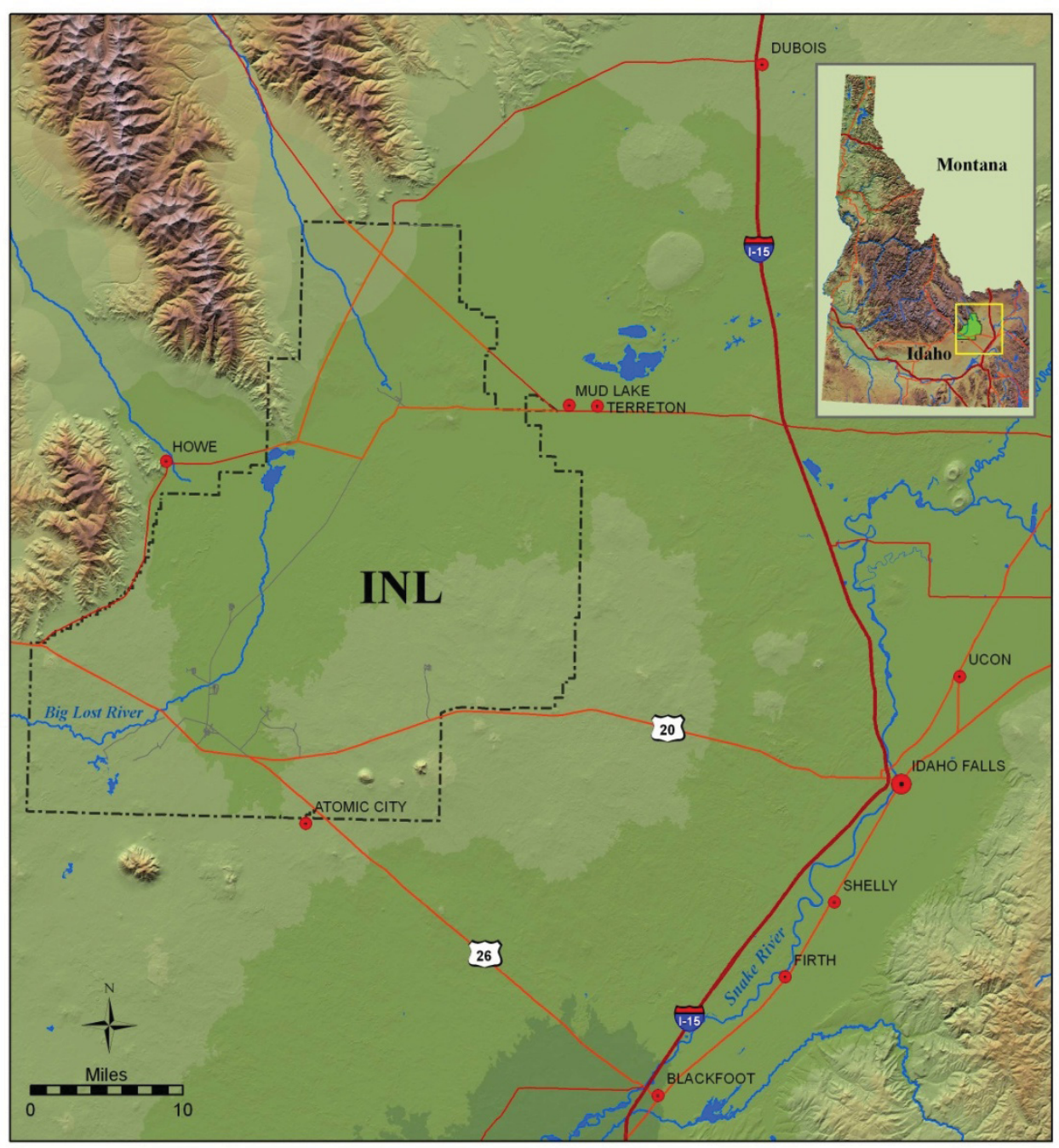

Figure 1. General location of the Idaho National Laboratory. 
Since its establishment in 1949 as the National Reactor Testing Station, the INL has made significant scientific contributions to the development of nuclear power across the Nation. This trend continues today as INL is designated as the lead national laboratory for development of new nuclear reactor technology. Research conducted at the Advanced Test Reactor Complex and Materials and Fuels Complex is critical to this mission (Figure 2). Various support systems are necessary to support this work. Among them is a capability to safely handle and dispose of remote-handled low-level waste (RH LLW). In order to maintain this important capability, a new facility is proposed (Harvego 2010a, 2010b). This report documents archival research and field investigations to identify cultural resources located in the two preferred alternative locations for construction of this new facility. Recommendations for future strategies to avoid any adverse impacts to identified cultural resources are also included. The document is presented in a specific format preferred by the Idaho State Historic Preservation Office (Idaho SHPO 1995) and required by the INL CRM Plan (DOE-ID 2009).

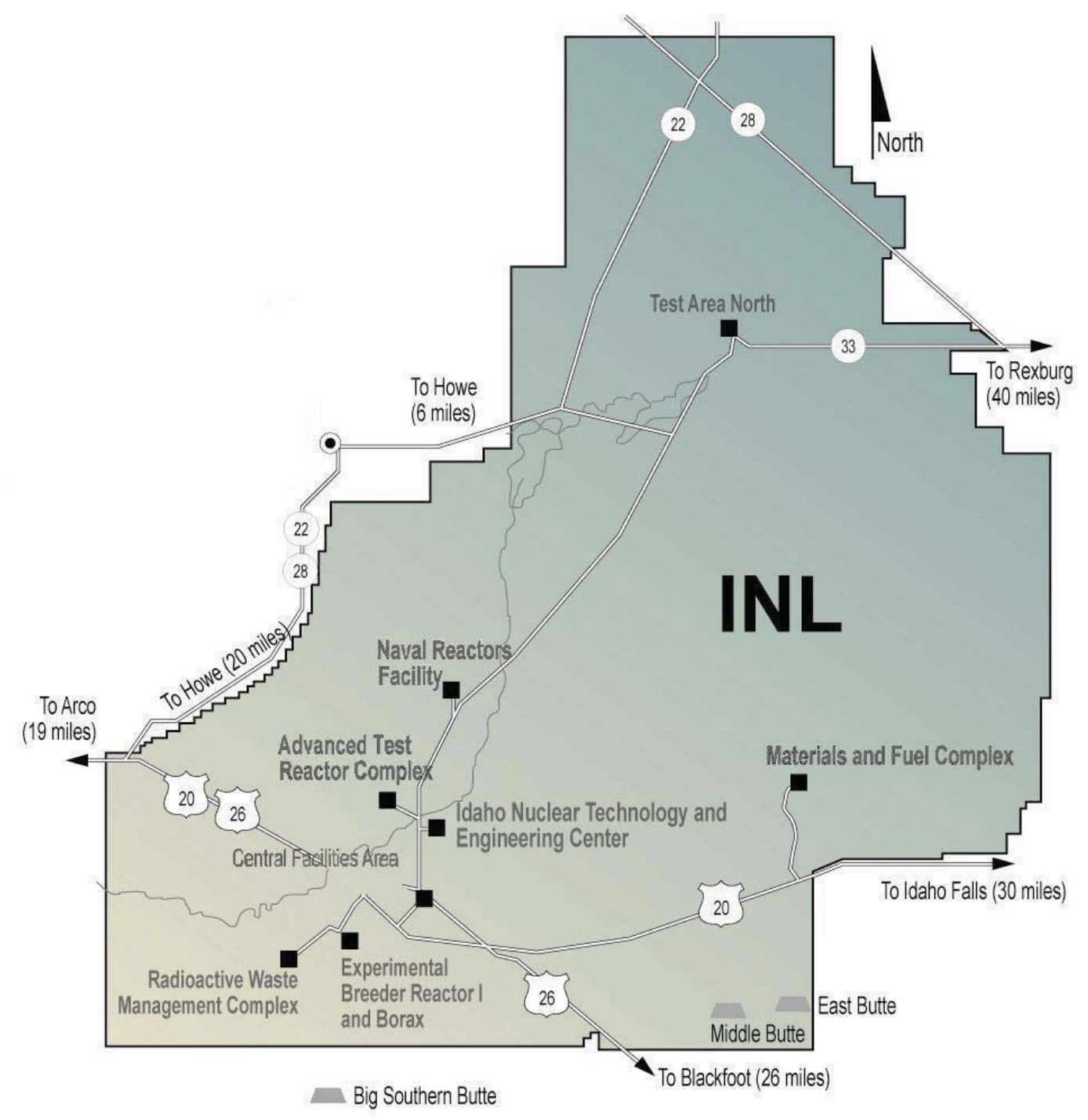

Figure 2. Idaho National Laboratory facilities. 


\section{PROJECT DESCRIPTION}

Ongoing and future nuclear-related missions of INL require a continued capability to appropriately handle and dispose of remote-handled low-level waste (RH LLW). Cleanup and closure of INL's existing onsite disposal facility at the Radioactive Waste Management Complex (RWMC) will result in the need for a replacement facility. Several candidate locations for construction of this new facility have been considered (Harvego et al. 2010a, 2010b) and two locations have been identified for further analysis.

The RH LLW facility to be built within one of the candidate locations will encompass approximately 4 - 6 acres, with additional areas needed to support changes to basic utility infrastructure (e.g. water, power, telecommunication, access roads). Figure 3 provides a conceptual footprint for the new facility. Vaults shown in this figure would be excavated 30 - $40 \mathrm{ft}$ deep into Big Lost River floodplain deposits. Ground disturbance within the footprint is expected to be intensive, involving heavy equipment to reshape the land surface and build the chosen facilities and support structures.

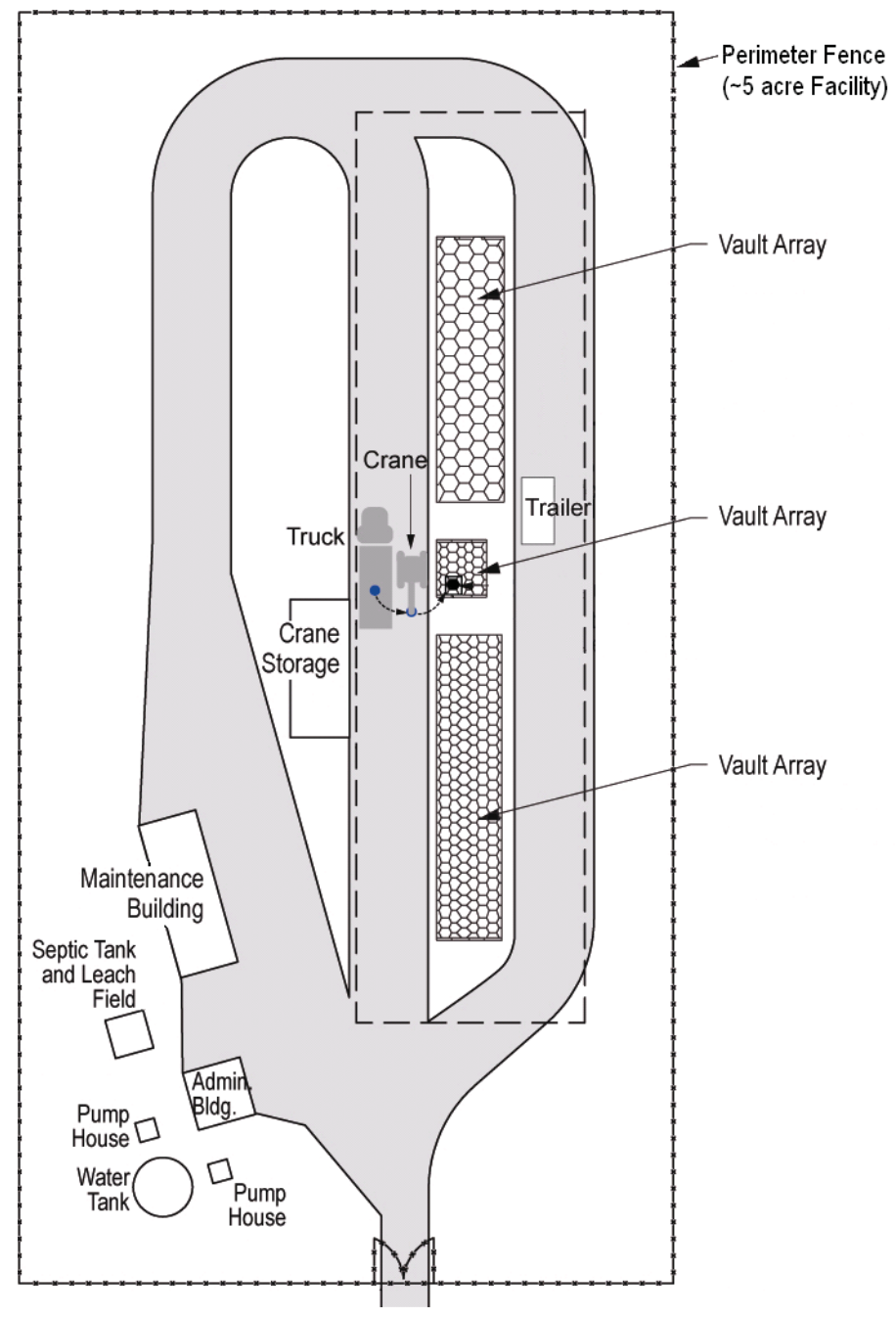

Figure 3. Conceptual layout for the proposed Remote Handled Low Level Waste Disposal Facility (based on Harvego et al. 2010b:4-1). 


\subsection{Area of Potential Effects}

There are two 45-acre plots under consideration for construction of the RH LLW facility (Figure 4). The facility that will eventually be built in one of these areas is expected to encompass approximately 4- 6 acres with some additional areas required for access and utility connections. A definitive area of potential effects for the project cannot be determined until a location is selected for construction. Once a decision is made, all proposed activities associated with construction of the facility are expected to be contained within the chosen 45-acre plot and will likely only cause impacts in a small portion of that area. However, utility connections may extend beyond. Archaeological survey coverage was extended to the nearest paved road beyond the 45 -acre candidate locations for construction in areas that are likely to be needed for these project elements.

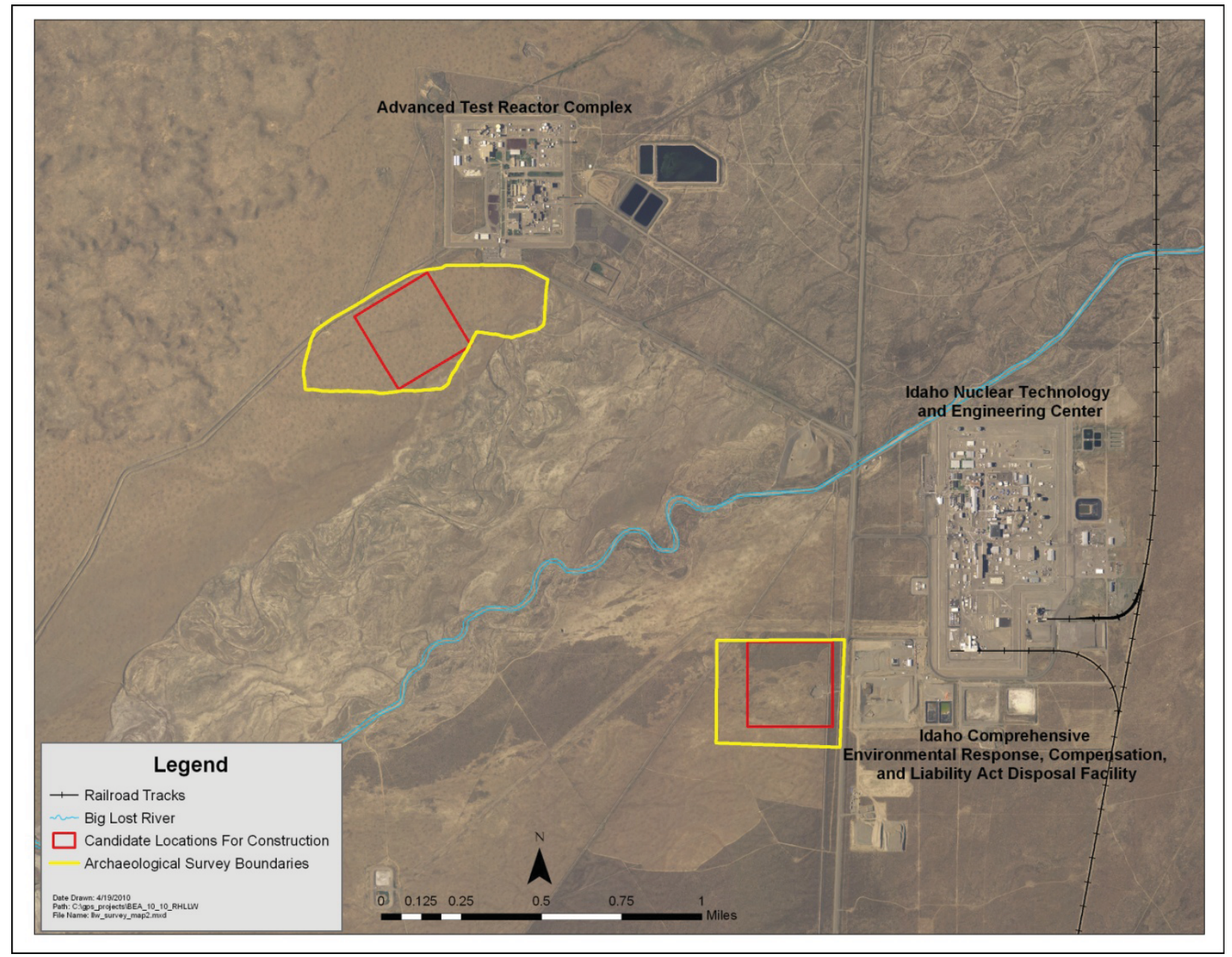

Figure 4. Candidate locations for construction of the Remote Handled Low Level Waste Facility and extent of archaeological survey coverage.

Archaeological resources and natural resources of importance to the Shoshone-Bannock Tribes located in the selected 45-acre area could be subject to direct impact during construction of the RH LLW facility and associated infrastructure. Impacts will primarily result from heavy equipment operations. Once construction is completed and the new RH LLW facility is in operation, new direct impacts are unlikely. However, indirect impacts to cultural resources may result from an increase in overall activity 
in a previously undeveloped portion of the INL. Archaeological sites, wildlife, and plants may be impacted by increased traffic, introduction and spread of invasive/noxious weeds, casual visitation, and unauthorized artifact collection.

\subsection{Project Acreage}

Facility construction will eventually be contained within one of two 45-acre candidate locations. Utility connections may extend beyond these plots. Archaeological surveys were extended beyond the 45-acre plots to encompass areas that may be suitable for utility and access road connections. In all, a total of 130 acres were surveyed near the ATR Complex and 70 acres were surveyed near the ICDF.

\subsection{Landowner}

Lands within the boundaries of INL are under the jurisdiction of the U.S. Department of Energy, Idaho Operations Office (DOE-ID) with the assistance of DOE-ID's prime operations contractor, Battelle Energy Alliance (BEA) and the Idaho Cleanup Project contractor, CH2M-WG Idaho, LLC (CWI). Lands within the Naval Reactors Facility are not administered by DOE-ID. Within INL grazing areas, administration is also shared with the Bureau of Land Management, Upper Snake River District, which issues and administers permits for these activities. Both candidate locations for construction of the RH LLW facility are located on lands under the sole jurisdiction of DOE-ID. 


\section{STATEMENT OF OBJECTIVES FOR INVESTIGATIONS}

The cultural resource investigations reported herein were conducted to satisfy three basic and interrelated goals:

- Identify cultural resources within the two candidate locations for construction of the RH LLW facility and adjacent areas that may be impacted by utility connections

- Conduct a preliminary assessment of the potential effects of construction activities on any identified cultural resources, particularly those listed on or eligible for listing on the National Register of Historic Places

- Develop recommendations for strategies to help ensure that effects to identified cultural resources are not adverse when construction plans are finalized

\subsection{Description of Area Investigated}

The two 45-acre candidate locations for RH LLW construction were the focus of the cultural resource investigations reported herein. Archaeological surveys were also expanded beyond the 45 -acre candidate locations in order to provide for future flexibility in placement of facility components as well as utility and access road connections. Survey coverage near the ATR Complex encompassed 130 acres and near the ICDF 70 acres were surveyed (Figure 4).

\subsection{Amount and Types of Information Collected}

All cultural resources investigations completed at INL must meet the Secretary of the Interior's standards under 36 CFR Part 800, as well as the tailored requirements outlined in the INL CRM Plan (DOE-ID 2009). In general, ground disturbing projects at INL are preceded by several types of data collection including: cultural resource archive searches, archaeological reconnaissance surveys in previously examined areas, and/or intensive archaeological surveys in areas that have never been systematically inventoried for cultural resources. Representatives from the Shoshone-Bannock Tribes are involved in INL field surveys and are invited to assist in the identification and protection of resources of traditional cultural or religious importance. All of these activities are designed to identify cultural resources in the areas of potential effect for proposed activities.

Investigations conducted to support the RH LLW project were designed to ensure that all archaeological resources with visible surface remains were identified within the 45 -acre candidate locations for facility construction as well as adjacent lands that may be needed to support utility and access connections. A representative from the Shoshone-Bannock Tribe's Heritage Tribal Office was also escorted to view the candidate locations to identify Native American cultural resources. Once plans for the actual RH LLW facility and associated utilities are finalized, additional cultural resource coordination will be necessary to ensure that resources with potential for eligibility to the National Register of Historic Places are not adversely impacted by construction. Section 9.0 provides recommendations for the monitoring and coordination that will accomplish this protection. 


\section{LOCATION AND GENERAL ENVIRONMENTAL SETTING}

Both of the candidate locations for construction of the RH LLW facility are located in the core developed area of the INL near the ATR Complex, Idaho Nuclear Technology and Engineering Center (INTEC) and the ICDF, and Central Facilities Area (CFA). Figure 4 illustrates the locations. A companion set of maps included in Appendix $\mathrm{C}$ depict archaeological resources identified within the candidate locations.

\subsection{Legal Locations}

Table 1. Legal locations for candidate locations for RH LLW facility construction.

\begin{tabular}{|c|l|c|}
\hline $\begin{array}{c}\text { AREA OF POTENTIAL } \\
\text { EFFECTS }\end{array}$ & \multicolumn{1}{|c|}{ LEGAL LOCATION } & $\begin{array}{c}\text { ARCHAEOLOGICAL } \\
\text { SURVEY COVERAGE }\end{array}$ \\
\hline $\begin{array}{c}\text { Candidate location near } \\
\text { ATR Complex (45 acres) }\end{array}$ & $\begin{array}{l}\text { Southern } 1 / 2 \text { Section 14 and northern } 1 / 4 \\
\text { Section 23, T3N, R29E, Butte County }\end{array}$ & 130 acres \\
\hline $\begin{array}{c}\text { Candidate location near } \\
\text { ICDF (45 acres) }\end{array}$ & $\begin{array}{l}\text { Northern } 1 / 2 \text { Section } 25 \text { and southern } 1 / 2 \\
\text { Section 24, T3N, R29E, Butte County }\end{array}$ & 70 acres \\
\hline
\end{tabular}

\subsection{Setting}

The INL is located in the high cool desert environment of the northeastern Snake River Plain. Aeolian, alluvial, and lacustrine sediments of varying thicknesses overlie basaltic lava flows within the 890 square mile Laboratory complex. The Big Lost River flows in a northeasterly direction from the southwestern corner of the Laboratory to eventually terminate in a series of natural sinks near the foothills of the Lemhi Mountains. An extensive floodplain follows the course of the River and in the vicinity of the sinks, a myriad of channels is cut into the now-dry bed of Pleistocene Lake Terreton. Vegetation is generally sparse and dominated by a community of low shrubs like sage and rabbitbrush, a wide variety of grasses and forbs, and occasional juniper trees. Many animals make their homes in this sagebrush grassland including pronghorn, deer, elk, coyotes, badgers, rabbits, many birds including raptors, game birds, and waterfowl, a wide variety of small rodents, and several types of small reptile.

Additional details on INL human history are provided in INL's Cultural Resource Management Plan (DOE-ID 2009). In general, the entire region has long been attractive to human populations. For Native American hunter-gatherers who probably utilized the area on a seasonal basis over at least 12,000 years, game animals and useful plants were found in abundance and nearby Big Southern Butte was attractive for the obsidian toolstone that outcrops near it's crest.

Within the last 150 years, emigrants began to pass through the area along a northern spur of the Oregon Trail (Goodale's Cutoff). Soon thereafter, early homesteaders sought to harness the waters of the Big Lost River and transform sagebrush flats into green pastures. Hundreds of settlers were encouraged by various federal laws like the Desert Land Act of 1877 and Carey Land Act of 1894 to file claims for INL lands at this time (ca. 1878 - 1930) and a massive system of canals and ditches was constructed to irrigate the newly created fields.

Few of these early settlers were able to "prove-up" on their claims and by 1930 most of the homesteads were abandoned. By the early 1940s, the remote and largely uninhabited lands that remained became attractive to the U.S. government for establishment of a Naval Proving Ground to test fire large battleship guns and conduct other ordnance-related research in support of U.S. military applications during World War II. After this initial period of military use, the U.S. Atomic Energy Commission designated the land as the National Reactor Testing Station and it became the Nation's primary testing ground for an emerging nuclear research program after 1949. The Laboratory has filled a similar role for 
more than 50 years, ultimately influencing nearly every power reactor in the world particularly in regard to design and safety (Stacey 2000).

Both of the candidate locations for RH LLW facility construction are located in similar topographic situations on the Big Lost River floodplain within a mile of the currently active River channel. In both areas, deep deposits of alluvial gravel cover a broad expanse that is bounded some distance to the northwest and southeast by surface outcrops of basalt lava. The topography is generally subdued with elevations averaging $4930 \mathrm{ft}$ above mean sea level and ranging only $5-10 \mathrm{ft}$ from that mean. Features of note include the active channel of the Big Lost River, which passes between the two candidate locations, and some older meander scars from a more active time in the flooding history of the region. No channels or braids are present within either of the candidate locations for the RH LLW facility, but rounded gravel deposits cover the surface of the ground. Low sage, rabbitbrush, and various grasses form a thin vegetative cover. 


\section{PRE-FIELD RESEARCH}

The INL CRM Office maintains an active archive of cultural resource investigations conducted at INL. This includes a wide variety of supporting documentation as well as the following specific records:

- Reports of reconnaissance-level archaeological surveys completed before 1984

- Reports of intensive archaeological surveys completed after 1984, including site forms

- Reports of archaeological test excavations conducted on INL lands, including field notes

- Archaeological sensitivity maps with predicted resource densities (Ringe 1995, Holmer et al. 2002)

- $\quad$ Maps and survey notes from government-sponsored land surveys of INL lands, ca 1884-1949

- Historic aerial photos of INL lands taken in 1949

- Reports of architectural surveys of all DOE-ID owned INL buildings (Arrowrock 1997)

- Historic and current plot plans of INL buildings and facility areas

- Microsoft Access and geographical information systems (GIS) maps and databases with information specific to the archaeological sites and historic architectural properties identified at INL.

All archaeological investigations completed at INL are preceded by checks of these archival materials to determine the nature and extent of previous research in a given area.

\subsection{Sources of Information Checked}

Several sources of information were consulted prior to 2010 field work for the RH LLW facility, including the following specific records:

- INL CRM project files

- INL CRM archaeological site databases and GIS maps

- Archaeological survey reports

- Historic aerial photographs of the project area taken in 1949

\subsection{Summary of Previous Investigations}

INL facilities and developments surround both candidate locations for the RH LLW facility: the ATR Complex lies to the north, INTEC and ICDF to the east, and CFA to the south. Many archaeological surveys, some large and some small, have been conducted in these areas. Near the ATR Complex, a survey of the facility perimeter in 1985 resulted in the recording of no cultural resources within 100 meters of the external perimeter fence (Reed et al. 1987a). Archaeological finds have been more numerous during surveys to support expansion of a large gravel pit located between the ATR Complex and INTEC. Surveys here in 1986, 1989, and 1994 (Reed et al. 1987b, Ringe 1989, Ringe 1994) have resulted in the documentation of four archaeological resources representative of both historic and prehistoric activities. A significant number of archaeological resources have also been found in various locations proposed for construction of new percolation ponds for INTEC (Ringe 1990, Ringe 2000). The areas investigated for these projects are to the south of the ATR Complex and west of INTEC and ICDF. More than 22 archaeological resources have been identified, including both prehistoric and historic sites potentially eligible to the National Register of Historic Places.

All of the previous surveys completed in the vicinity of the proposed RH LLW facility are peripheral to the candidate locations for construction and none resulted in the recording of cultural resource within the 45-acre plots or in adjacent areas where utility and access connections might be placed. 


\subsection{Evaluation of Previous Investigations}

Since 1984, archaeological surveys of INL lands have been intensive and conducted according to the standards currently outlined in the INL CRM Plan (DOE-ID 2009). Prior to this time, INL archaeological surveys were not necessarily intensive and documentation may not meet current standards. Previous surveys in the vicinity of the candidate locations for the RH LLW facility were intensive. However, they were completed more than ten years ago. Under the INL CRM Plan, areas that were intensively surveyed more than ten years ago are subject to new archaeological reconnaissance when new ground-disturbing projects are proposed there. This policy helps to ensure that any area proposed for new ground disturbance is intensively examined (transect interval $\leq 20 \mathrm{~m}$ ) and that all cultural resources with visible surface remains are documented.

The intensive archaeological surveys conducted of the candidate locations for the RH LLW facility in 2010 included thin slivers of land that were initially examined in 1985 during previous surveys of the ATR Complex perimeter and Lincoln Blvd. (Reed et al. 1987a). However, most of the acres surveyed in 2010 had never been surveyed for cultural resources. Since all areas within the RH LLW project were intensively surveyed or resurveyed in 2010, it is likely that all National Register-eligible resources with visible surface remains in the project areas have been identified. 


\section{EXPECTED HISTORIC AND PREHISTORIC LAND USE AND SITE DENSITY}

Previous archaeological investigations in the vicinity of the candidate locations for construction of the RH LLW facility provide the basis for estimates of cultural resource density and distribution in the project area as presented in the sections to follow.

\subsection{Known or Expected Resources}

No cultural resources have been previously recorded within the boundaries of either candidate location for RH LLW facility construction or in nearby areas that may be used for utility and access connections. However a variety of resources have been identified in the surrounding area. Within the inventory of these known, previously recorded cultural resources in the vicinity are short term hunting campsites, tool modification localities, and isolated artifacts from the prehistoric period $(\sim 12,000-150$ years BP). Late $19^{\text {th }}$ and early $20^{\text {th }}$ Century homesteads, short term activity areas, isolated artifacts, historic trails, canals and ditches have also been recorded. During previous surveys in the vicinity, significant prehistoric sites tended to cluster along abandoned channels of the Big Lost River and topographically featureless expanses of the floodplain tended to yield only isolated prehistoric artifacts. In contrast, the floodplain has been demonstrated to contain a rich historic record, yielding important finds related to early agricultural development and settlement.

\subsection{Known or Expected Themes, Time Periods, and INL Contexts}

The following Tables illustrate the general themes, time periods, and INL-specific contexts documented within the archaeological record in the vicinity of the candidate locations for RH LLW facility construction.

Table 2. General themes and time periods anticipated in the project area.

\begin{tabular}{|l|l||l|}
\hline \multicolumn{2}{|c||}{ THEMES } & \multicolumn{1}{c|}{ TIME PERIODS } \\
\hline$[\mathrm{x}]$ Archaeology & {[] Military } & {$[\mathrm{x}]$ Prehistoric } \\
\hline$[\mathrm{x}]$ Agriculture & {$[\mathrm{d}$ Mining } & {$[\mathrm{x}]$ Historic Native American } \\
\hline[] Architecture & {$[\mathrm{x}]$ Native Americans } & {$[\mathrm{x}]$ Exploration: $1805-1860$} \\
\hline[] Civilian Conservation Corps & {[] Politics/Government. } & {$[\mathrm{x}]$ Settlement: $1855-1890$} \\
\hline$[\mathrm{x}]$ Commerce & {$[\mathrm{x}]$ Public Land Management } & {$[\mathrm{x}]$ Statehood: $1890-1904$} \\
\hline[] Communication & {$[\mathrm{x}]$ Recreation/Tourism } & {$[\mathrm{x}]$ Statehood: $1904-1920$} \\
\hline[] Culture and Society & {$[\mathrm{x}]$ Settlement } & {$[\mathrm{x}]$ Interwar: $1920-1940$} \\
\hline[]$]$ Ethnic heritage & {$[$ ] Timber } & {$[$ ] Pre-Modern: $1940-1958$} \\
\hline[] Exploration/Fur Trade & {$[\mathrm{x}]$ Transportation } & {$[$ ] Modern: $1958-$ present } \\
\hline[] Industry & {$[\mathrm{x}]$ Other: Irrigation } & \\
\hline
\end{tabular}

Table 3. INL-specific contexts anticipated in the project area.

\begin{tabular}{|l|l|l|}
\hline $\begin{array}{l}\text { [x] Prehistoric Native } \\
\text { American: } 15,000-150 \mathrm{BP}\end{array}$ & $\begin{array}{l}\text { [ ] Ordnance Testing, Naval } \\
\text { Proving Ground: } 1942-1949\end{array}$ & $\begin{array}{l}\text { [ ] Nuclear Reactor Testing, } \\
\text { Development: } 1955-1970\end{array}$ \\
\hline $\begin{array}{l}\text { [x] Historic Native American: } \\
150 \text { BP - present }\end{array}$ & [ ] Ordnance Testing, Vietnam & $\begin{array}{l}\text { [ ] Post Nuclear Reactor Research: } \\
\text { 1971 - present }\end{array}$ \\
\hline $\begin{array}{l}\text { [x] Euro American Contact/ } 1968-1970 \\
\text { Settlement: } 1805-1942\end{array}$ & [ ] Nuclear Reactor Testing, & $\begin{array}{l}\text { [ ] Remediation of Nuclear Waste: } \\
\text { 1971 - present }\end{array}$ \\
\hline
\end{tabular}




\section{METHODS OF INVESTIGATION}

All work during the 2010 cultural resource investigations for the RH LLW facility was performed in a manner consistent with formal and informal standards and guidelines issued by the Idaho SHPO, the Advisory Council on Historic Preservation, the National Park Service, and Department of Interior, as outlined in DOE-ID's CRM Plan (DOE-ID 2009).

\subsection{Field Techniques}

The field survey tactics employed during the project were designed to provide intensive visual coverage of the current ground surface to ensure that all archaeological resources with visible surface remains were identified. Intensive surveys at INL are accomplished through the use of systematic pedestrian transects with surveyors walking no more than 20 meters apart, typically in skirmish line fashion. In 2010, in the 45-acre candidate locations, transects were oriented according to existing roads, canals, and other features. A hand-held GPS unit with sub-meter accuracy was used to navigate to the 45acre plots and ensure that both were surveyed in their entirety. GPS data were also collected to pinpoint the locations of a newly identified archaeological resources and to map artifact distributions. Fieldwork in all areas was facilitated by trouble-free access on existing roads.

In general, when cultural materials are encountered during an intensive survey transect, previous survey records, including site forms, are consulted to determine if the newly discovered artifacts are associated with a known site or isolate location. At all newly discovered artifacts, careful searches $(3-5$ meter survey intervals) are conducted to ascertain the current boundaries of the resource and to pinpoint temporally or functionally diagnostic artifacts, artifact concentrations, cultural features, or areas of postdepositional disturbance. If the newly discovered artifacts fall within or near the original boundaries of a previously recorded site or isolate, monitoring forms are completed to document the location and current condition of the resource and note any new discoveries. When single unmodified flakes or tin cans are identified in areas where no previously recorded resources were present, notations are made on field maps and notes, but no formal site recording forms are prepared. Occurrences of $2-9$ flakes or cans or $1-9$ diagnostic artifacts in areas where no previously recorded resources were present are classified as "isolates" and are formally recorded. Formal recording is also completed for "sites" ( $\geq 10$ artifacts within 100 meters or any number of items within an active geologic setting).

During the 2010 RH LLW surveys, six resources were newly discovered within the two candidate locations for construction and surrounding surveyed areas. INL-tailored recording forms were completed for all of these resources and these forms are included in Appendix D. In all cases, newly found diagnostic artifacts were photographed or sketched and their relative positions were recorded with the GPS unit. No artifacts were collected for permanent curation during the 2010 surveys.

\subsection{Surface Conditions}

Sparse vegetation at INL typically provides excellent surface visibility. In the candidate locations for construction of the RH LLW facility, approximately $80 \%$ of the ground was un-obscured. Sunny conditions prevailed for most of the days spent in the field.

\subsection{Areas Not Examined}

All proposed project areas were intensively examined. This included both of the 45 -acre candidate locations for RH LLW facility construction. Survey coverage was also extended around these plots in areas that may be needed to support utility and access road construction.

\subsection{Native American Involvement}

INL complies with and follows federal and state laws and regulations, DOE policies, and INLspecific management plans that define how DOE and its contractors will interact with Native Americans. 
More specifically, DOE-ID recognizes its trust responsibility to the Shoshone-Bannock Tribes, whose aboriginal lands include the INL. In the spirit of that responsibility, DOE-ID has entered into an Agreement in Principle (AIP) with the Tribes (DOE-ID 2007). In addition to defining a broad range of interests and working relationships, the AIP devotes particular attention to the management of INL cultural resources. Broadly, its intent is to foster confidence on the part of the Shoshone-Bannock Tribes that INL cultural resources are managed in a spirit of protection and stewardship. To achieve this, the AIP provides for routine tribal participation in new and ongoing INL projects with an open invitation to comment on, visit, observe, and/or assist in cultural resource management investigations.

In 2010, a representative from the Shoshone-Bannock Tribe's Heritage Tribal Office was taken on a tour of both 45-acre candidate locations for RH LLW construction and information was presented on the project at regularly scheduled meetings of the Cultural Resource Working Group in April, May, and June. No specific concerns about Native American cultural resources in the candidate locations for construction were expressed. However, more general concerns about disturbances to plants and animals were noted.

\subsection{Field Personnel}

All field work during the 2010 investigation was conducted by INL CRM Office personnel: Hollie Gilbert coordinated the intensive archaeological surveys with assistance from Julie Braun Williams, Dino Lowrey, and Clayton Marler. Carolyn Smith from the Shoshone-Bannock Tribes participated in the tribal tour conducted by Clayton Marler.

\subsection{Dates of Fieldwork}

Fieldwork was conducted in April and May of 2010.

\subsection{Problems Encountered}

No problems were encountered. 


\section{RESULTS}

In 2010, two 45-acre candidate locations for construction of the RH LLW facility and nearby lands that may be needed to support utility and access development were intensively surveyed for cultural resources. Near the ATR Complex, surveys encompassed 130 acres and four archaeological resources were identified, including a historic homestead (BEA-10-10-6), historic canals (BEA-10-10-5), and two isolated prehistoric artifacts (BEA-10-10-3, BEA-10-10-4). Near the ICDF, 70 acres were examined and two archaeological resources were identified, including a small historic activity area (BEA-10-10-1) and a historic canal and ditch (BEA-10-10-2). Specific Native American cultural resources were not officially documented by the Shoshone-Bannock Tribes in the candidate locations for construction of the RH LLW facility. However, a representative from the Tribe's Heritage Tribal Office toured the project areas and concerns with regard to protection of the natural environment have been documented.

Additional information on the resources confirmed to be within the boundaries of the two candidate locations for RH LLW construction is provided in the Sections to follow. INL CRM site recording forms with detailed documentation are provided in Appendix D and all of the resources are plotted on maps in Appendix C. Legal restrictions on the distribution of sensitive information detailing the exact location of archaeological resources may result in the removal of these Appendices from some versions of this report.

\subsection{Resources Identified}

Table 4. Archaeological resources identified in the two candidate locations for RH LLW construction.

\begin{tabular}{|c|c|c|c|}
\hline SITE NO. & DESCRIPTION & $\begin{array}{l}\text { RELATIONSHIP } \\
\text { TO PROJECT }\end{array}$ & 2010 OBSERVATIONS \\
\hline BEA-10-10-1 & $\begin{array}{l}\text { Activity Area } \\
\text { Historic Period } 1805- \\
1942\end{array}$ & $\begin{array}{l}\text { Candidate Location } \\
\text { west of ICDF } \\
\text { Northern portion }\end{array}$ & $\begin{array}{l}\text { Light scatter of domestic debris (milk, } \\
\text { food, and tobacco cans, amber bottle, } \\
\text { shaving lotion tube, milled wood, } \\
\text { galvanized wash tub, metal sign for } \\
\text { "Dad Clay's Garage") dating to } 1936\end{array}$ \\
\hline BEA-10-10-2 & $\begin{array}{l}\text { Canal and Ditch } \\
\text { Historic Period } 1878- \\
1930\end{array}$ & $\begin{array}{l}\text { Candidate Location } \\
\text { west of ICDF } \\
\text { Northwestern portion } \\
\end{array}$ & Secondary canal and hand-dug ditch \\
\hline BEA-10-10-3 & $\begin{array}{l}\text { Isolated Artifact } \\
\text { Middle Prehistoric Period } \\
\text { 7,500 - 1,300 BP }\end{array}$ & $\begin{array}{l}\text { Candidate Location } \\
\text { near ATR Complex } \\
\text { Northwestern corner }\end{array}$ & $\begin{array}{l}\text { Nondiagnostic ignimbrite dart point } \\
\text { fragment (Middle Prehistoric 7,500 - } \\
3,500 \text { years BP) }\end{array}$ \\
\hline BEA-10-10-4 & $\begin{array}{l}\text { Isolated Artifact } \\
\text { General Prehistoric Period } \\
12,000-150 \mathrm{BP}\end{array}$ & $\begin{array}{l}\text { Candidate Location } \\
\text { near ATR Complex } \\
\text { Southwestern corner }\end{array}$ & Retouched flake of chalcedony \\
\hline BEA-10-10-5 & $\begin{array}{l}\text { Canals } \\
\text { Historic Period } 1878- \\
1930\end{array}$ & $\begin{array}{l}\text { Candidate Location } \\
\text { near ATR Complex } \\
\text { Northern portion }\end{array}$ & Primary and secondary canals \\
\hline BEA-10-10-6 & $\begin{array}{l}\text { Homestead } \\
\text { Historic Period } 1878 \text { - } \\
1930\end{array}$ & $\begin{array}{l}\text { Candidate Location } \\
\text { near ATR Complex } \\
\text { Northern portion }\end{array}$ & $\begin{array}{l}\text { Extensive scatter of domestic debris } \\
\text { (cans, window glass, bottles, ceramics, } \\
\text { nails, sewing machine, plow parts, } \\
\text { corset stays, milled lumber, shovel, } \\
\text { stove pipe, bailing wire, etc.) with } \\
\text { distinct concentrations that may } \\
\text { represent cultural features (e.g. dump, } \\
\text { living area, livestock area). A primary } \\
\text { canal, secondary canal, and historic } \\
\text { trail are also associated. }\end{array}$ \\
\hline
\end{tabular}




\subsection{Resources Noted But Not Recorded}

All archaeological materials observed within the two candidate locations for RH LLW construction were formally recorded. Based on tribal involvement in the 2010 fieldwork, it is likely that contemporary Native American resource values are also present, but the Shoshone-Bannock Tribes have not pinpointed any of these resources at this time. General tribal concerns regarding impacts to natural resources (e.g. plants and animals) have been noted.

\subsection{Summary of Important Characteristics of Identified Resources}

All of the archaeological resources identified within the two candidate locations for RH LLW construction contribute to the overall base of knowledge of prehistoric and historic use of the northeastern Snake River Plain. Appendix D contains site recording forms for each of the resources identified and Appendix C provides detailed locational information.

The two isolated artifacts represented in the inventory (BEA-10-10-3, BEA-10-10-4) probably reflect light, hunting-related use of the Big Lost River vicinity during the Prehistoric period from approximately 12,000 - 150 years BP. Finds like this are common across the high desert lands of the INL. They represent short-term activities by the hunter-gatherers who lived here at this time and are unlikely to yield any information beyond that which was collected during the initial field recording.

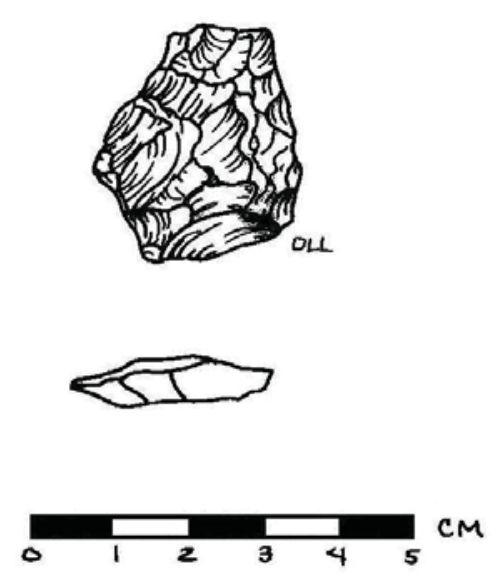

A

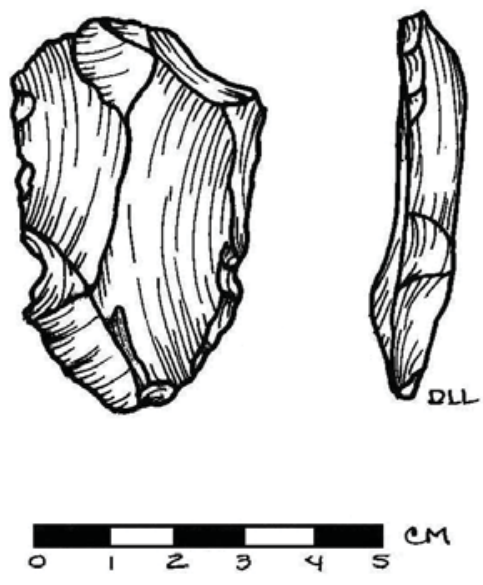

B

Figure 5. Isolated artifacts discovered during the RH LLW surveys: large notched point fragment from BEA-10-10-3 (A) and retouched flake from BEA-10-10-4 (B).

Historic archaeological resources like those identified in the two candidate locations for RH LLW construction represent a variety of activities associated with agricultural development and late $19^{\text {th }}$-early $20^{\text {th }}$ Century homesteading on the Big Lost River floodplain. Many of these resources hold promise for addressing research questions related to the cultural and political dynamics of this time from roughly 1878 - 1930. In this context, Site BEA-10-10-6 is a homestead that exhibits good integrity with little or no modern disturbance and is clearly associated with intensive domestic activities (Figure 6). Cultural features, possibly including a main living area, an outhouse, and a barn or livestock area may be present. 


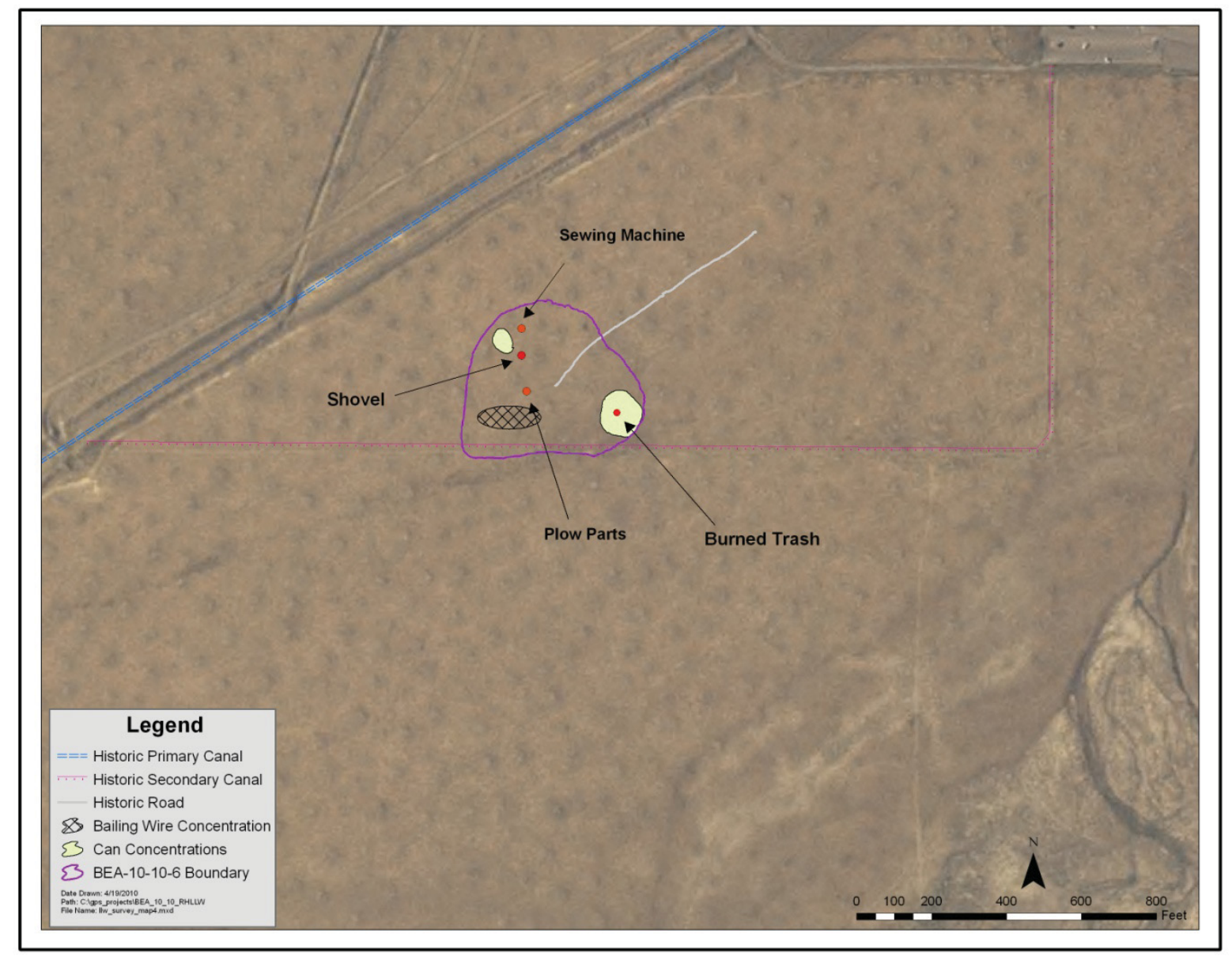

Figure 6. Planimetric map of homestead site, BEA-2010-10-6.

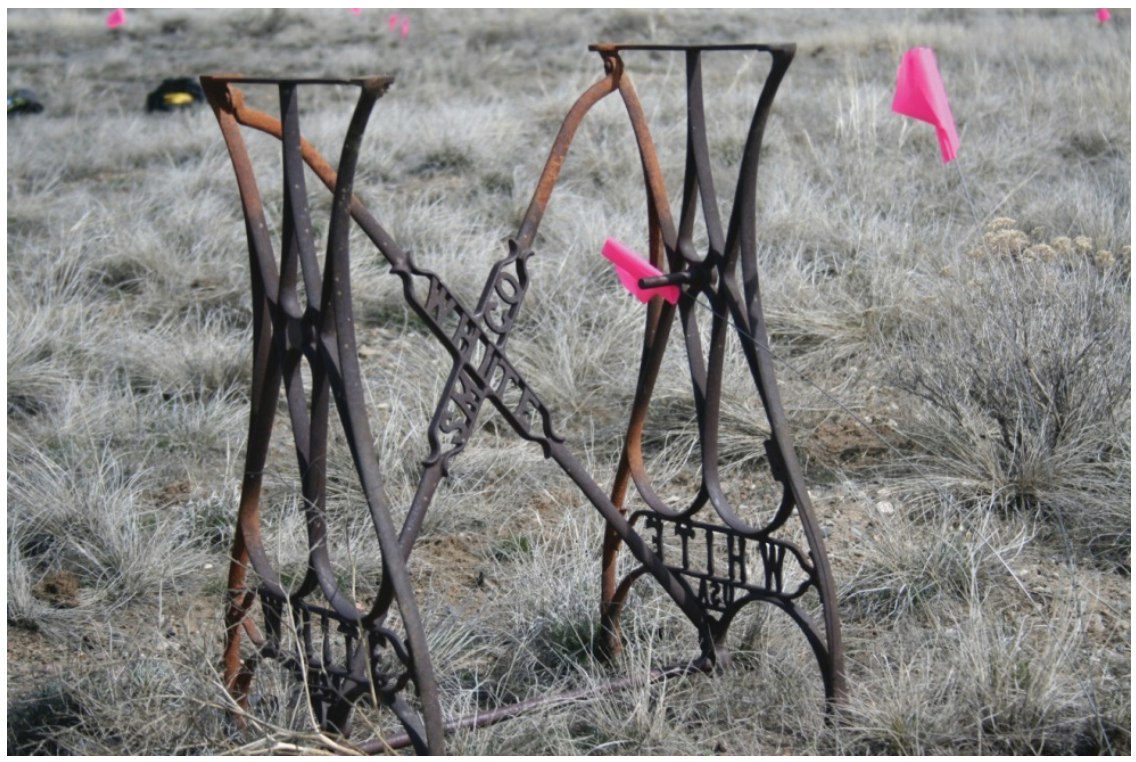

Figure 7. Sewing machine stand discovered at homestead site BEA-2010-10-6. 
The extensive trash dump also appears to exhibit some stratification, which could aid in investigation and interpretation. Additional information of importance in understanding historic settlement of the INL region may be gathered from this homestead through standard archaeological techniques as well as archival research.

The canals and ditches (BEA-10-10-5) associated with the homestead site (Figure 6) and located elsewhere within the two candidate locations for RH LLW facility construction (BEA-10-10-2) contribute to the larger cultural landscape and infrastructure associated with agricultural development during this time and also retain excellent integrity in spite of some modern interruptions along or through their banks. Standard archaeological techniques and a variety of archival methods could be employed to enhance understanding of the engineering techniques employed to build these structures, to define associated features (i.e. head gates, bridges, ditches, etc.), and map the extent of the water delivery system in relation to homesteads, trails, and other important features. A clearer picture of activities associated with INL's brief period of historic settlement and agricultural development from roughly 1878 - 1930 would emerge from these efforts.

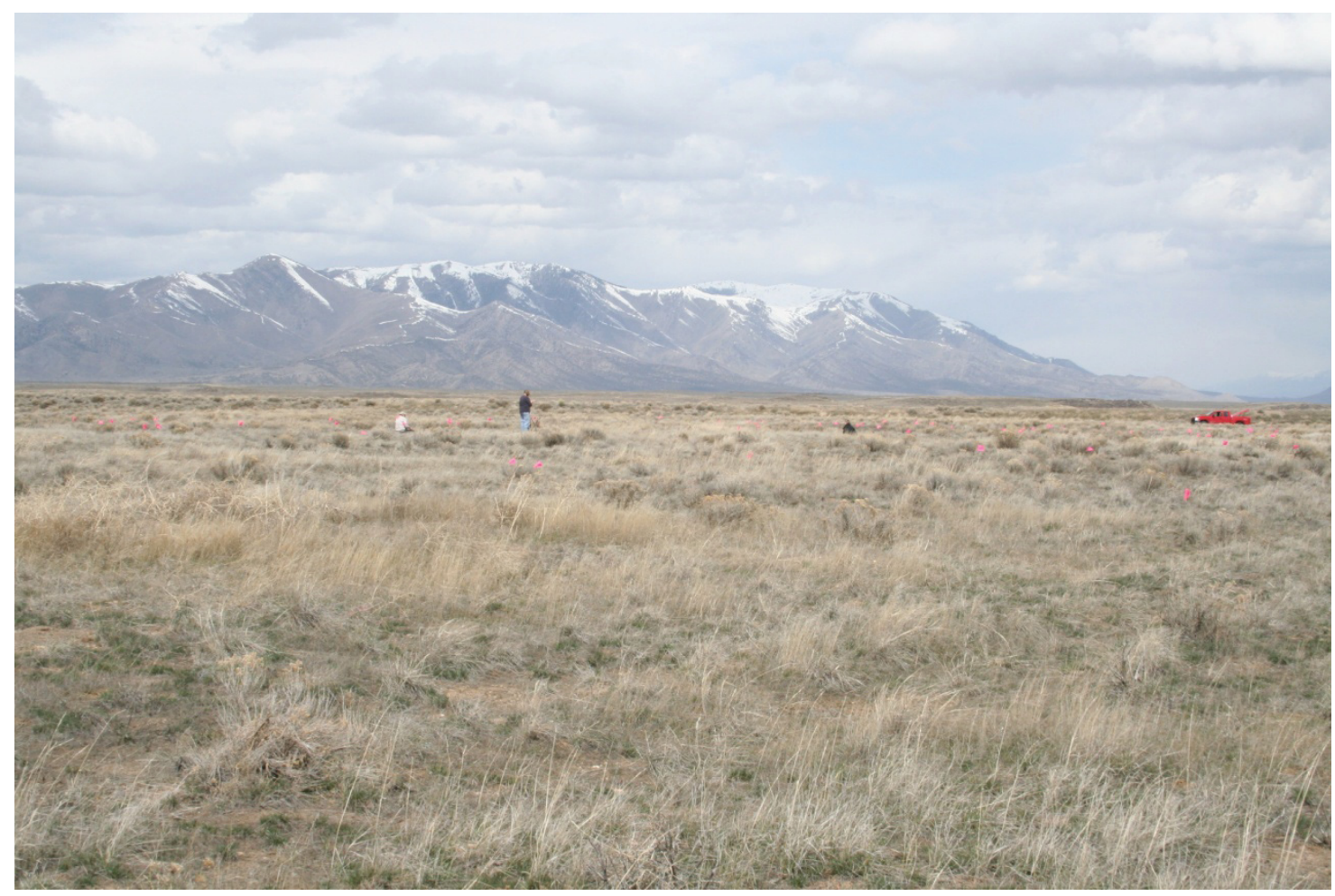

Figure 8. Secondary canal (BEA-10-10-5) extending left to right through lower portion of photo near historic homestead site (BEA-10-10-6). 
Site BEA-10-10-1 is a small activity area with relatively recent artifacts definitively dating to 1936 . During this time, homesteading activities and agricultural development were no longer intensive in the INL area. However, evidence that historic travelers continued to pass through the region on their way to nearby communities is clear in the artifacts found. The sign advertising "Dad Clay's Garage" (Figure 9) was one of hundreds placed on major and minor roads to attract tourist and residents to the garage in Idaho Falls in the early 1900s (Fritzen 1991). A road sign like this may have become a short-term stopping point for travelers and the light scatter of historic debris present near it is indicative of transitory activities. It is unlikely that cultural features are present at this location and the potential for future investigations is low.

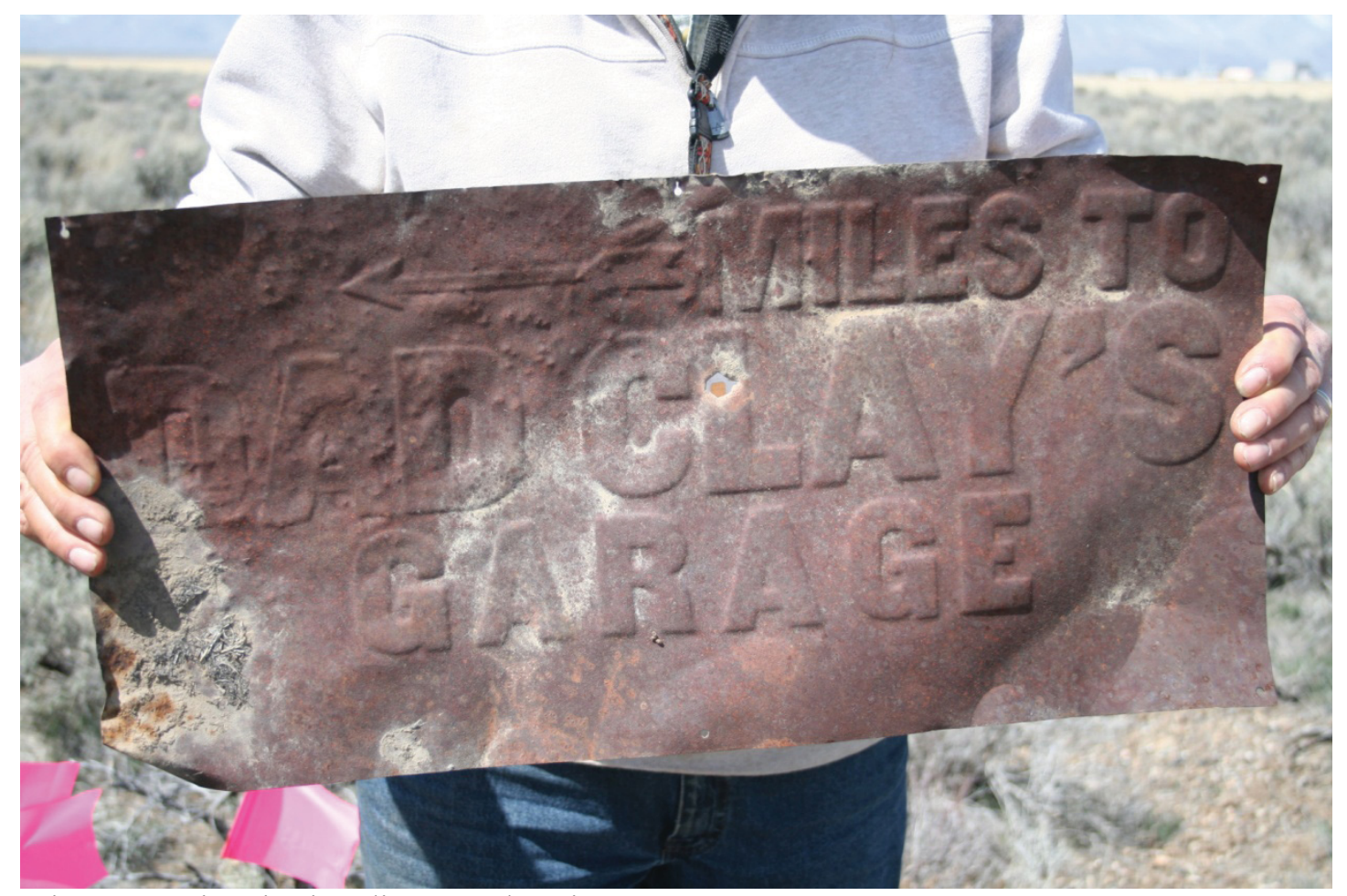

Figure 9. Historic sign discovered at site BEA-10-10-1.

\subsection{National Register Eligibility}

Archaeological resources related to historic settlement and agricultural development identified in the candidate locations for construction of the RH LLW facility include a large homestead and several irrigation canals and ditches. All of these resources are potentially eligible for nomination to the National Register of Historic Places either individually or as part of a larger historic district related to INL's period of settlement and agricultural development from approximately 1878 - 1930.

Each candidate location for RH LLW construction was also found to contain resources that are evaluated as ineligible for nomination to the National Register. This includes a small historic activity area from 1936 and two isolated prehistoric artifacts. None of these resources are likely to yield any additional information beyond that which was collected during the initial recording effort.

Table 5 provides summaries of the National Register assessments completed for all resources located in the RH LLW project areas. 
Table 5. National Register evaluations for archaeological resources identified in the two candidate locations for RH LLW construction.

\begin{tabular}{|c|c|c|c|c|}
\hline Field No. & Eligibility & Criterion & $\begin{array}{l}\text { General Themes } \\
\text { and Time Periods }\end{array}$ & INL Contexts \\
\hline $\begin{array}{l}\text { BEA-10-10-1 } \\
\text { Small Historic } \\
\text { Activity Area }\end{array}$ & Not Eligible & N/A & $\mathrm{N} / \mathrm{A}$ & N/A \\
\hline $\begin{array}{l}\text { BEA-10-10-2 } \\
\text { Historic Canal } \\
\text { and Ditch }\end{array}$ & $\begin{array}{l}\text { Potentially } \\
\text { Eligible as } \\
\text { part of larger } \\
\text { historic } \\
\text { district }\end{array}$ & $\begin{array}{l}\quad \text { "c" } \\
\text { Distinctive } \\
\text { regional } \\
\text { developments } \\
\text { and construction } \\
\text { methods }\end{array}$ & $\begin{array}{l}\text { Agriculture } \\
\text { Settlement } \\
\text { Irrigation } \\
\text { Statehood: } 1904 \text { - } \\
1920\end{array}$ & $\begin{array}{l}\text { Euro American } \\
\text { Contact/Settlement: } \\
1805-1942 \\
\text { Agricultural } \\
\text { Development: } 1878 \text { - } \\
1930\end{array}$ \\
\hline $\begin{array}{l}\text { BEA-10-10-3 } \\
\text { Isolated } \\
\text { Prehistoric } \\
\text { Artifact }\end{array}$ & Not Eligible & N/A & N/A & N/A \\
\hline $\begin{array}{l}\text { BEA-10-10-4 } \\
\text { Isolated } \\
\text { Prehistoric } \\
\text { Artifact }\end{array}$ & Not Eligible & N/A & N/A & $\mathrm{N} / \mathrm{A}$ \\
\hline $\begin{array}{l}\text { BEA-10-10-5 } \\
\text { Historic Canals }\end{array}$ & $\begin{array}{l}\text { Potentially } \\
\text { Eligible as } \\
\text { part of larger } \\
\text { historic } \\
\text { district }\end{array}$ & $\begin{array}{l}\quad \text { "c" } \\
\text { Distinctive } \\
\text { regional } \\
\text { developments } \\
\text { and construction } \\
\text { methods }\end{array}$ & $\begin{array}{l}\text { Agriculture } \\
\text { Settlement } \\
\text { Irrigation } \\
\text { Statehood: } 1904 \text { - } \\
1920\end{array}$ & $\begin{array}{l}\text { Euro American } \\
\text { Contact/ Settlement: } \\
1805-1942 \\
\text { Agricultural } \\
\text { Development: } 1878 \text { - } \\
1930\end{array}$ \\
\hline $\begin{array}{l}\text { BEA-10-10-6 } \\
\text { Historic } \\
\text { Homestead }\end{array}$ & $\begin{array}{l}\text { Individually } \\
\text { Eligible }\end{array}$ & $\begin{array}{l}\quad \text { "d" } \\
\text { Information } \\
\text { Potential }\end{array}$ & $\begin{array}{l}\text { Agriculture } \\
\text { Settlement } \\
\text { Irrigation } \\
\text { Settlement: } 1855 \text { - } \\
1890 \\
\text { Statehood: } 1890 \text { - } \\
1904 \\
\text { Statehood: } 1904 \text { - } \\
\text { 1920 }\end{array}$ & $\begin{array}{l}\text { Euro American } \\
\text { Contact/ Settlement: } \\
1805-1942 \\
\text { Agricultural } \\
\text { Development: } 1878 \text { - } \\
1930\end{array}$ \\
\hline
\end{tabular}




\section{CONCLUSIONS AND RECOMMENDATIONS}

The discussion to follow provides a synthesis of identified resources, potential impacts, and recommendations for avoiding adverse cultural resource impacts during construction of the RH LLW facility in either of the candidate locations currently under consideration.

\subsection{Summary of Investigations}

Cultural resource investigations completed to determine the potential impacts of a new RH LLW facility in one of two identified candidate locations for construction included cultural resource archive searches, intensive archaeological field surveys, and communication with Shoshone-Bannock tribal representatives. Both candidate locations for construction are approximately 45 acres in size, but only 4-6 acres within these plots are likely to be impacted by the new facility. Archaeological surveys were focused in these 45-acre areas, but also extended beyond to cover areas that may be needed to support utility and access road connections. At the candidate location for construction near the ATR Complex, 130 acres were intensively surveyed and four archaeological resources were identified. At the candidate location for construction near ICDF, 70 acres were intensively surveyed and two archaeological resources were identified. Appendix D contains INL site recording forms with additional detail on the identified resources and exact locations are plotted on maps included in Appendix C.

The candidate location for RH LLW construction near the ATR Complex contains four archaeological resources. Among these are two isolated artifacts, which provide important information on broad patterns of prehistoric human use of the region. However, they are unlikely to yield any additional information and are consequently evaluated as ineligible for nomination to the National Register of Historic Places. A large primary canal and associated secondary canal are also located in this candidate location. From a design standpoint, portions of these canals stand as excellent examples of early $20^{\text {th }}$ Century canal construction methods and they are also associated with a distinctive pattern of regional settlement and agricultural development. They are potentially eligible to the National Register as part of a larger historic district. The fourth archaeological resource located in this candidate location is a historic homestead that is individually eligible for nomination to the National Register for its potential to yield additional information important in understanding the period from roughly 1878 - 1930, when homesteading and agricultural development activities were at their peak in the INL region.

The candidate location for RH LLW construction near the ICDF contains two archaeological resources. One of these is a small activity area reflecting short term transitory activities around 1936. This resource provides important information for understanding the period of transition between agricultural development and establishment of the Atomic Energy Commission's National Reactor Testing Station, which eventually became the INL. However, it is unlikely to yield any additional information and as a result, is evaluated as ineligible for nomination to the National Register of Historic Places. This candidate location also contains a historic, hand-dug ditch that may be eligible for nomination to the National Register as part of a historic district associated with settlement and agricultural development in the region.

Finally, although no Native American cultural resources have been specifically identified within either of the candidate locations for construction of the RH LLW facility, representatives from the Shoshone-Bannock Tribes have indicated that native plants and animals across the INL area are of tribal importance.

\subsection{Potential Threats to Identified Resources}

Ground disturbance associated with the construction of the RH LLW facility and associated infrastructure (i.e. utilities, access roads, telecommunications, etc.) will be intensive and has the potential to impact any archaeological sites and natural resources of importance to the Shoshone-Bannock Tribes in the chosen footprint of the project. In addition to direct impacts from heavy equipment and earth-moving, 
archaeological sites and Native American resources identified in the area could also be subject to indirect impacts during construction as a result of higher visibility on the landscape and overall increases in activity levels in a previously undeveloped area. Artifacts may be subject to unauthorized collection or impacted by unauthorized off-road vehicle use. Resident and migratory birds and animals may be disturbed and noxious and invasive weeds may increase.

All of these activities could jeopardize the integrity of archaeological resources in the candidate location ultimately chosen for construction. A final assessment of impacts will not be possible until project plans are finalized. However, it is possible at this time to outline general measures that can be implemented to prevent adverse impacts to the identified resources.

\subsection{Recommendations for Additional Investigations or Protective Measures}

Adverse effects to cultural resources in the candidate locations for RH LLW construction can be minimized by slight modification of project plans to avoid archaeologically sensitive areas as well as a variety of more specific protection measures. After plans are finalized with specific details on ground disturbing activities it will be necessary to fine-tune these strategies to achieve the desired protection. If resources can be avoided and/or the protection measures established, it is likely that the project can be completed with no adverse effects to archaeological resources or natural resources of importance to the Shoshone-Bannock Tribes.

Cultural resource protection strategies could be accomplished by implementing the following types of activities, depending on details of the final construction plans:

- Continue communication and coordination with the Shoshone-Bannock Tribes;

- Initiate consultation with the Idaho State Historic Preservation Office;

- Design the RH LLW facility footprint to avoid direct impacts to all identified cultural resources, but particularly the historic homestead (BEA-10-10-6) and historic canals and ditches;

- If construction will occur within 50 meters of the historic homestead (BEA-10-10-6), consider installation of fencing or other methods of marking the sensitive area and preventing inadvertent disturbance;

- If avoidance of the historic homestead (BEA-10-10-6) is not feasible, conduct additional archaeological investigations, including test excavations, in advance of ground disturbance to catalog and preserve the important information and materials before damage occurs;

- If avoidance of historic canals and ditches (BEA-10-10-2, BEA-10-10-3) is not feasible, conduct additional investigations to ensure that comparable intact sections of these features are preserved elsewhere on INL;

- If avoidance of prehistoric isolates (BEA-10-10-3, BEA-10-10-4) and the small historic activity area (BEA-10-10-1) is not feasibly, complete full documentation of impacted artifacts and consider systematic collection for permanent curation and/or relocation to a nearby surface context that will not be disturbed after full documentation of these intentional changes to the original spatial distribution of the artifacts;

- Depending on final construction plans, conduct cultural resource monitoring of ground disturbance in sensitive areas with authority to temporarily redirect work to salvage any sensitive materials uncovered;

- Conduct cultural resource sensitivity training for project personnel to discourage unauthorized artifact collection, off-road vehicle use, and other activities that may impact cultural resources and encourage a sense of stewardship for cultural resources, including tribally sensitive plants and animals. 
- Minimize disturbance to plant and wildlife species important to the Shoshone-Bannock Tribes by possible implementation of seasonal and time of day restrictions on ground disturbance, good housekeeping, and/or revegetation of disturbed areas with native plant species;

- Implement a Stop Work Procedure to guide the assessment and protection of any unanticipated discoveries of cultural materials during construction. 


\section{REPOSITORY}

Upon completion of the project, all documentation (i.e. site recording forms, photographs, reports, field notes, etc.) will be curated at the Southeastern Idaho Regional Archaeological Center located in the Idaho Museum of Natural History on the Idaho State University campus in Pocatello, Idaho.

Comprehensive permanent archives are also maintained at the INL CRM Office in Idaho Falls, ID. In the interim between field collection and permanent curation, all materials are kept in secure temporary storage at the INL CRM Office in Idaho Falls, Idaho. 


\section{REFERENCES}

Arrowrock Group Inc., 1997, The Idaho National Engineering and Environmental Laboratory: A Historical Context and Assessment, Narrative and Inventory, INEEL/EXT-97-01021, September 1997.

DOE-ID, 1997, Idaho National Engineering Laboratory Comprehensive Facility and Land Use Plan, DOE/ID-10514, December 1997.

DOE-ID, 2007, Agreement-in-Principle (between the Shoshone-Bannock Tribes and the U.S. Department of Energy), December 2007.

DOE-ID, 2009, Idaho National Laboratory Cultural Resource Management Plan, DOE/ID-10997, Rev. 3, February 2009.

Fritzen, Mary Jane, 1991, Idaho Falls: City of Destiny, Bonneville County Historical Society, Idaho Falls, ID.

Harvego, Lisa, Joan Connolly, Lance Peterson, Brennon Orr, and Bob Starr, 2010a, Siting Study for the Remote-Handled Low-Level Waste Disposal Project, INL/EXT-07-12902, January 2010.

Harvego, Lisa, David Duncan, Joan Connolly, Margaret Hinman, Charles Marcinkiewicz, and Gary Mecham, 2010b, Conceptual Design Report for the Remote-Handled Low-Level Waste Disposal Project, Rev. 2, INL/EXT-07-1290, April 2010.

Holmer, R. N., S. R. Plager, Brenda R. Pace, and T. Grieve, 2002, A GIS Predictive Model of Archaeological Sites in Eastern Idaho, $28^{\text {th }}$ Great Basin Anthropological Conference, Elko, NV, October 2002.

Idaho State Historic Preservation Office, 1995, "Idaho Archaeological and Historical Survey Manual: Guidelines for Identifying and Evaluating Cultural Properties," Historic Preservation Series No. 8, Boise, ID.

Irving, J. S., editor, 1993, Environmental Resource Document for the Idaho National Engineering Laboratory, EGG-WMO-10279, July 1993.

Ringe, Brenda, 1989, “Archaeological Investigations on the Idaho National Engineering Laboratory: the CPP/TRA Gravel Pit," Swanson/Crabtree Anthropological Research Laboratory Reports of Investigations: 89-1, Pocatello, ID.

Ringe, Brenda, 1990, Letter to W. R. Palica, Archaeological Report and Clearance Recommendation for the ICPP Percolation Pond No. 4, BLR-03-90, May 2, 1990. Document on file at the INL CRM Office, Idaho Falls, ID.

Ringe, Brenda, 1994a, Archaeological and Paleontological Investigations of Idaho National Engineering Laboratory Active Borrow Sources, EGG-CS-11284 and INEL-94/0254, September 1994.

Ringe, Brenda, 1995, Locational Analysis and Preliminary Predictive Model for Prehistoric Cultural Resources on the Idaho National Engineering Laboratory, MA thesis, Department of Anthropology, Idaho State University, Pocatello, ID.

Ringe, Brenda Pace, 2000, Cultural Resource Investigations for the Idaho Nuclear Technology and Engineering Center Service Wastewater Disposal Facility, INEEL/EXT-2000-00004, January 2000.

Reed, W. G., J. W. Ross, B. Ringe, and R. N. Holmer, 1987a, "Archaeological Investigations on the Idaho National Engineering Laboratory: 1984-1985, Revised Edition,” Swanson/Crabtree Anthropological Research Laboratory Reports of Investigations: 87-1, Pocatello, ID. 
Reed, W. G., J. W. Ross, B. Ringe, and R. N. Holmer, 1987b, “Annual Review of Archaeological Investigations on the Idaho National Engineering Laboratory: 1986" Swanson/Crabtree Anthropological Research Laboratory Reports of Investigations: 87-2, Pocatello, ID.

Stacey, S. M., 2000, Proving the Principle: a History of the Idaho National Engineering and Environmental Laboratory 1949 - 1999, DOE-ID/10799, December 2000. 
INTENTIONALLY BLANK 
Appendix A: Key Information 
INTENTIONALLY BLANK 


\section{Appendix A: Key Information}

A. Project name: Remote Handled Low Level Waste Facility

B. Project number: INL CRM Office BEA-2010-10

C. Agency name: Battelle Energy Alliance INL CRM Office for the Department of Energy Idaho Operations Office

D. Report authors: Brenda R. Pace, Hollie Gilbert, Julie Braun Williams, Clayton Marler, Dino Lowrey, Cameron Brizzee

E. Principal Investigator: Brenda R. Pace

F. Report date: June 2010

G. County: Butte County

H. Legal locations and Project/Survey Acreage:

\begin{tabular}{|c|l|l|}
\hline LEGAL LOCATION & \multicolumn{1}{|c|}{$\begin{array}{c}\text { AREA OF POTENTIAL } \\
\text { EFFECT }\end{array}$} & $\begin{array}{c}\text { ARCHAEOLOGICAL } \\
\text { SURVEY COVERAGE }\end{array}$ \\
\hline $\begin{array}{c}\text { Candidate location near ATR } \\
\text { Complex (45 acres) }\end{array}$ & $\begin{array}{l}\text { Southern } 1 / 2 \text { Section } 14 \text { and } \\
\text { northern } 1 / 4 \text { Section 23, T3N, } \\
\text { R29E, Butte County }\end{array}$ & 130 acres \\
\hline $\begin{array}{c}\text { Candidate location near ICDF } \\
\text { (45 acres) }\end{array}$ & $\begin{array}{l}\text { Northern } 1 / 2 \text { Section } 25, \text { T3N, } \\
\text { R29E, Butte County }\end{array}$ & 70 acres \\
\hline
\end{tabular}


INTENTIONALLY BLANK 


\section{Appendix B: Certification of Results}


INTENTIONALLY BLANK 


\section{Appendix B: Certification of Results}

\section{CERTIFICATION OF RESULTS:}

I certify that this investigation was conducted and documented according to Secretary of Interior's Standards and Guidelines and that this report is complete and accurate to the best of my knowledge.

(original signed by Brenda R. Pace)

Signature of Principal Investigator

Date 
INTENTIONALLY BLANK 


\section{Appendix C: Project Maps}


INTENTIONALLY BLANK 


\section{Appendix C: Project Maps}

Appendix C contains project maps that show the specific locations of cultural resources. However, only those resources located in the candidate locations for construction of the RH LLW facility are shown.

The locational information presented in these maps is distributed for Official Use Only and may have been removed from some versions of the document. It is exempted from the Freedom of Information Act under Section 9 of the Archaeological Resources Protection Act of 1979 (as amended) and under Section 304 of the National Historic Preservation Act of 1966 (as amended). Distribution of any cultural resource locational information from this document and particularly from this Appendix must be approved in advance by contacting the INL CRM Office, PO Box 1625-2105, Idaho Falls, ID 83415, telephone: (208) 526-0916. The following maps are included here:

- Map 1: Archaeological survey boundaries and candidate locations for RH LLW facility construction

- Map 2: Archaeological survey boundaries and candidate locations for RH LLW facility construction with archaeological resources (Official Use Only)

- Map 3: Archaeological survey boundaries and candidate locations for RH LLW facility construction with archaeological resources in relation to Section lines and INL facilities (Official Use Only

- Map 4: Planimetric map of site BEA-10-10-1 (Official Use Only)

- Map 5: Planimetric map of site BEA-10-10-6 (Official Use Only) 
INTENTIONALLY BLANK 


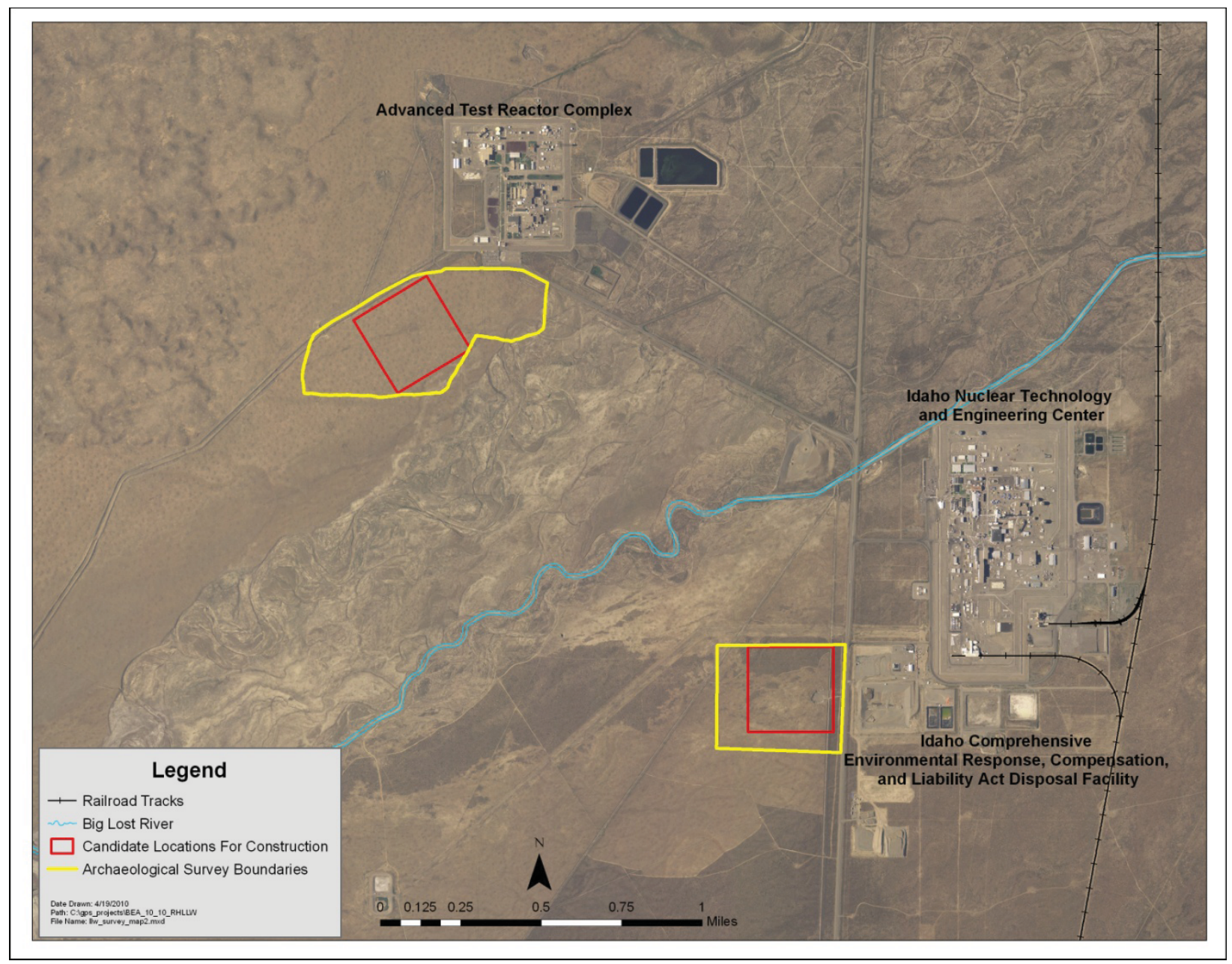

Map 1: Archaeological survey boundaries and candidate locations for RH LLW facility construction. 
Page Removed

(Official Use Only) 
Page Removed

(Official Use Only) 
Page Removed

(Official Use Only) 
Page Removed

(Official Use Only) 
INTENTIONALLY BLANK 
Appendix D: Site Recording Forms 
INTENTIONALLY BLANK 


\section{Appendix D: Site Recording Forms}

The locational information presented in these forms is distributed for Official Use Only and may have been removed from some versions of the document. It is exempted from the Freedom of Information Act under Section 9 of the Archaeological Resources Protection Act of 1979 (as amended) and under Section 304 of the National Historic Preservation Act of 1966 (as amended). Distribution of any cultural resource locational information from this document and particularly from this Appendix must be approved in

advance by contacting the INL CRM Office, PO Box 1625-2105, Idaho Falls, ID 83415, telephone: (208) 526-0916.

The following forms are included here:

- Isolated Find Records for BEA-10-10-3 and BEA-10-10-4

- Site Recording Forms for BEA-10-10-1 (small historic activity area), BEA-10-10-6 (Historic homestead), BEA-10-10-2 (Historic canal and ditch)and BEA-10-10-5 (Historic canals). 
INTENTIONALLY BLANK 
Page Removed

(Official Use Only) 
Page Removed

(Official Use Only) 
Page Removed

(Official Use Only) 
Page Removed

(Official Use Only) 
Page Removed

(Official Use Only) 
Page Removed

(Official Use Only) 
Page Removed

(Official Use Only) 
Page Removed

(Official Use Only) 
Page Removed

(Official Use Only) 
Page Removed

(Official Use Only) 
Page Removed

(Official Use Only) 
Page Removed

(Official Use Only) 
Page Removed

(Official Use Only) 
Page Removed

(Official Use Only) 
Page Removed

(Official Use Only) 
Page Removed

(Official Use Only) 
Page Removed

(Official Use Only) 
Page Removed

(Official Use Only) 